\title{
FOLD AND FAULT CONTROL ON THE DRAINAGE PATTERN OF A DOUBLE-KARST-AQUIFER SYSTEM, WINTERSTAUDE, AUSTRIAN ALPS
}

\author{
VPLIV GUB IN PRELOMOV NA NAČIN ODVAJANJA VODA \\ V DVOJNEM KRAŠKO-VODONOSNEM SISTEMU, \\ WINTERSTAUDE, AVSTRIJSKE ALPE
}

\author{
Nico GOLDSCHEIDER ${ }^{1} \&$ Christoph NEUKUM ${ }^{2}$
}

\begin{abstract}
UDC 911.2:551.435.8:556.3

Nico Goldscheider \& Christoph Neukum: Fold and fault control on the drainage pattern of a double-karst-aquifer system, Winterstaude, Austrian Alps

Lithostratigraphy and geologic structures are major controls on groundwater flow in alpine karst systems. Understanding these factors is important for the delimitation of drinking water protection zones. The Winterstaude mountain chain, western Austria, belongs to the Helvetic nappes and consists of Cretaceous sedimentary rocks, including two karstifiable formations: Örfla and Schrattenkalk Limestone (lower and upper karst aquifer), separated by $60 \mathrm{~m}$ of marl. Strata are folded and cut by faults with displacements of 40-70 m. Folded carbonate rocks continue below the alluvial valley floor so that the karst system can be subdivided in shallow and deep phreatic zones. This area is suitable for studying the combined influence of folds and faults on groundwater flow in a double-aquifer system. A multi-tracer test with seven injections aimed at characterising hydraulic connections and linear flow velocities. Results show that (i) plunging synclines form the main drainage pathways in the upper karst aquifer, with maximum linear velocities of $91 \mathrm{~m} / \mathrm{h}$, while anticlines act as water divides; (ii) recharge into the lower aquifer, which forms the central ridge of the mountain chain, contributes to springs discharging from the upper aquifer near the foot of the mountain (local flow systems); (iii) the two aquifers are hydraulically connected, presumably via faults, because their displacements are in the same order of magnitude as the thickness of the intervening marl; (iv) flow in the upper aquifer continues below the valley floor toward the river, with maximum velocities of $22 \mathrm{~m} / \mathrm{h}$ (intermediate flow system).
\end{abstract}

Keywords: alpine hydrogeology, multi-aquifer system, crossformational flow, fold tectonics, multi-tracer test, Austria.
Povzetek

UDK 911.2:551.435.8:556.3

Nico Goldscheider \& Christoph Neukum: Vpliv gub in prelomov na način odvajanja voda $v$ dvojnem kraško-vodonosnem sistemu, Winterstaude, Avstrijske Alpe

Litostratigrafija in geološke strukture so poglavitne za vpliv na tok podzemne vode $\mathrm{v}$ alpskih kraških sistemih. Razumevanje teh faktorjev je pomembno za razmejitev vodovarstvenih pasov. Gorska veriga Winterstaude v zahodni Avstriji pripada Helvetskemu pokrovu in se sestoji iz krednih sedimentnih kamnin, vključno z dvema zakraselima formacijama apnencev: Örfla in Schrattenkalk (spodnji in gornji kraški vodonosnik), ki ju ločuje $60 \mathrm{~m}$ laporja. Plasti so nagubane in prekinjene s prelomi in premikom za 40-70 m. Nagubane karbonatne kamnine se nadaljujejo pod dnom aluvialne doline, tako da je kraški sistem razdeljen na plitvo in globoko freatično cono. Takšno območje je primerno za proučevanje vpliva gub in prelomov na tok podzemne vode v dvojnem vodonosnem sistemu. Cilj večsledilnega poskusa s sedmimi injicirnimi točkami je bil označitev hidravličnih povezav in linearnih hitrosti toka. Rezultati so pokazali, da (i) potopljene sinklinale tvorijo glavne odvodne poti $\mathrm{v}$ gornjem kraškem vodonosniku $\mathrm{z}$ najvišjimi linearnimi hitrostmi $91 \mathrm{~m} / \mathrm{h}$, medtem ko antiklinale predstavljajo razvodnice; (ii) napajanje spodnjega vodonosnika, ki oblikuje osrednji greben gorske verige, prispeva k izvirom, ki iztekajo iz gornjega vodonosnika ob vznožju gora (lokalni pretočni sistem); (iii) oba vodonosnika sta hidravlično povezana, domnevno preko prelomov, saj je njihov zamik istega velikostnega razreda, kot je debelina vmesnega laporja; (iv) tok v gornjem vodonosniku se nadaljuje pod dnom doline proti reki $\mathrm{z}$ najvišjimi hitrostmi $22 \mathrm{~m} / \mathrm{h}$ (vmesni pretočni sistem).

Ključne besede: alpska hidrogeologija, sistem večih vodonosnikov, tok preko formacij, prelomna tektonika, večsledilni poskus, Avstrija.

\footnotetext{
${ }^{1}$ Technische Universität München (TUM), Department for Civil, Geo- and Environmental Engineering, Hydrogeology and Geothermics Group, Arcisstr. 21, 80333 Munich, Germany, e-mail: goldscheider@tum.de

${ }^{2}$ Department of Engineering Geology and Hydrogeology, RWTH Aachen University, 52064 Aachen, Germany

Received/Prejeto: 16.11.2009
} 


\section{INTRODUCTION}

Geologic structures, such as folds and faults, are major influences on speleogenesis and on the underground drainage of alpine and other karst systems (Burkhard et al. 1998; Goldscheider 2005; Häuselmann et al. 1999; Herold et al. 2000). Many communities and cities in the alpine region, such as Vienna, use drinking water from

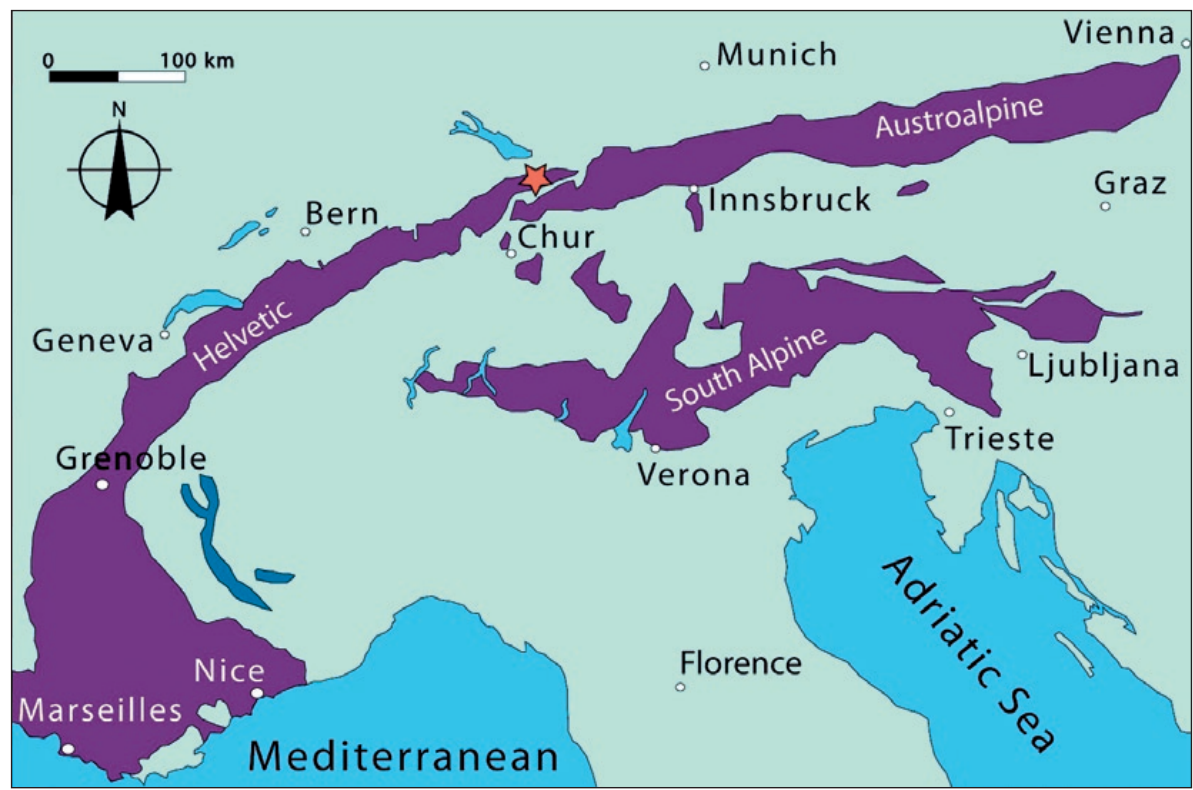

Fig. 1: Karst areas in the Alps (dark cyan) and location of the study area Winterstaude (red star), situated near the NE end of the Helvetic zone. Karst areas outside the Alps are not shown.

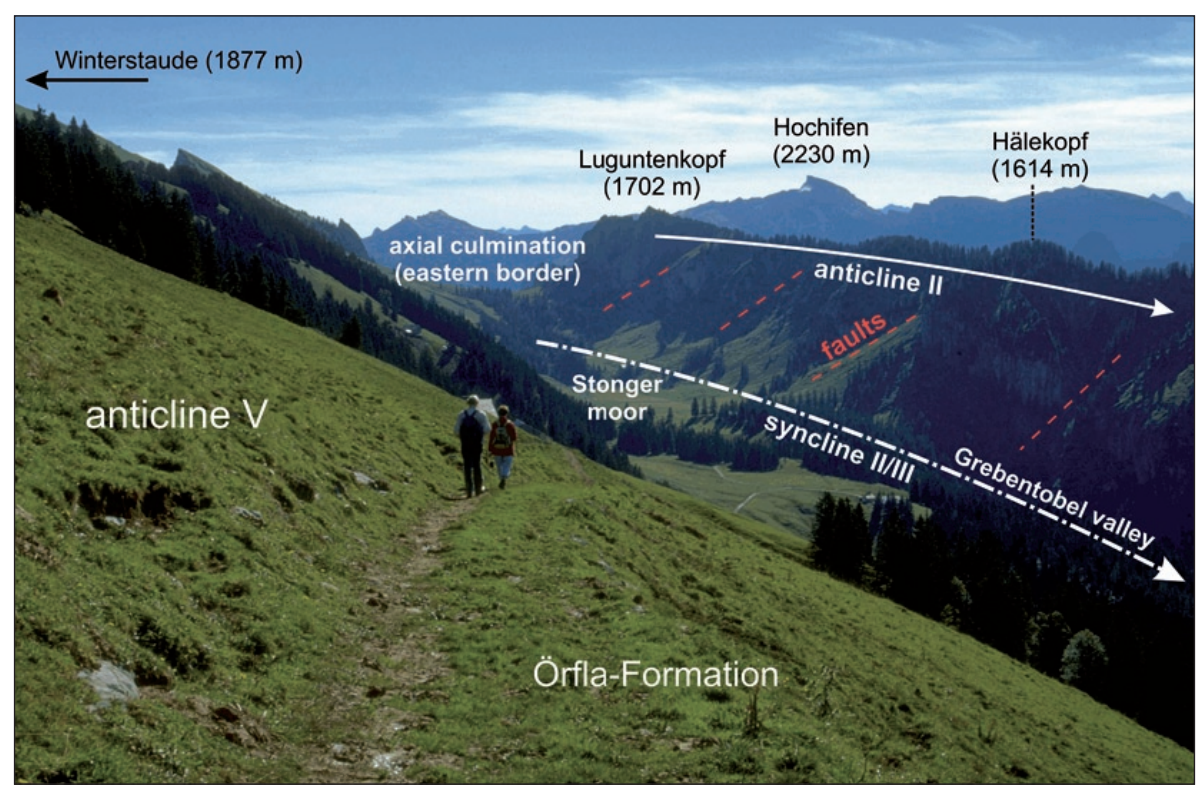

Fig. 2: Impression of the study area: Outcrops of Örfla Limestone show little karst development; two major anticlines and a syncline predominate the landscape. Several NE-faults with displacements of 40-70 $\mathrm{m}$ cut anticline II. The Hochifen-Gottesacker karst area is visible in the background (Photo: N. Goldscheider). karst aquifers, often abstracted from springs or drainage galleries (Plan et al. 2010). The sustainable management of these freshwater resources requires the implementation of appropriate source protection zones, which is only possible if catchment boundaries are known in detail.

The Alps are subdivided into four geological units: Helvetic, Penninic, Austroalpine, and South Alpine (Schmid et al. 2004). Carbonate rocks are present in all four domains, but particularly widespread in the Northern Calcareous Alps (Austria, Germany) of the Austroalpine domain, and in the external parts of the Western Alps (France, Switzerland, Western Austria), belonging to the Helvetic zone (Fig. 1). Thick Triassic limestone and dolomite sequences predominate in the Austroalpine domain, while large parts of the Helvetic nappes consist of Jurassic to Cretaceous alternations of limestone, marl and sandstone.

Consequently, Austroalpine karst aquifers are often very thick, and drainage is controlled by fractures and faults, by the dip of the underlying aquiclude and by the topographic-hydrologic boundary conditions (Maloszewski et al. 2002; Plan et al. 2009). Helvetic karst systems show different drainage patterns, influenced by the presence of intervening lowpermeability formations. A higher degree of stratigraphic flow control also means that folds have a larger influence on drainage. The HochifenGottesacker area (AustroGerman Alps, Fig. 2) is a prime example of this type of 
karst system. It consists of a single karst aquifer, ca. 100 $m$ thick, underlain by marl. Tracer tests demonstrated that anticlines act as local drainage divides, while plunging synclines form the main drainage pathways, at least where the aquifer basis is above the hydrologic base level (Goldscheider 2005).

While the relations between folds and karst drainage are relatively easily predictable in single-aquifer systems, many other karst systems in the Helvetic zone and elsewhere consist of several aquifers and intervening aquitards, and are more intensely faulted. For example, tracer tests in the Tsanfleuron-Sanetsch area (Swiss Alps) demonstrated rapid cross-formational flow between two karst aquifers, across several marl formations, along deep fractures (Gremaud et al. 2009). The relations between stratigraphic-tectonic elements and underground drainage in complex karst systems have rarely been studied systematically.
Within the framework of an applied project focusing on the delineation of source protection zones for the community of Bezau, Austria, the hydrogeology of the Winterstaude mountain chain has been studied in detail (Figs. 1 and 2). This karst system consists of two limestone aquifers and several marly formations, folded and cut by faults. The community uses drinking water from springs at the foot of this mountain chain, but the water is frequently contaminated by faecal bacteria from cattle pasture and wastewater releases at farmhouses and restaurants.

The practical goal of this study was to identify contamination sources and delineate spring catchments, so as to propose improved protection schemes. The scientific goal, and the focus of this article, is to characterise the drainage pattern of this complex karst system and to obtain insights into the role of folds and faults on groundwater flow in multi-aquifer systems.

\section{GEOLOGIC AND HYDROLOGIC SETTING}

\section{LITHOSTRATIGRAPHY}

The Winterstaude chain belongs to the Helvetic zone and is formed by Cretaceous sedimentary rocks (Figs. 1 and 3). The oldest formations are exposed in anticlines while the younger ones occur along synclines (Figs. 4 and 5). The Palfris Marl (Berriasian) is the oldest formation; it is several hundreds of metres thick, but only ca. $120 \mathrm{~m}$ outcrop in the study area.

The Örfla formation (Berriasian to Lower Valanginian) is $160 \mathrm{~m}$ thick and consists of oolitic limestone with thin banks of sandstone and marl. It outcrops along anticlines and forms the crest of the mountain chain (Figs. 2 and 5). A thin condensation horizon represents the Valanginian; Hauterivian sediments were not deposited (Wyssling 1986).

The Drusberg formation (Barremian) is hundreds of metres thick in other parts of the Helvetic zone but only ca. $60 \mathrm{~m}$ in the study area; it consists of marl including limestone banks.

The Schrattenkalk formation (Barremian-Aptian), known as Urgonian in other parts of the Alps, is 60$120 \mathrm{~m}$ thick and consists of pure limestone (97\% calcite). The Drusberg and Schrattenkalk formations outcrop in long, narrow strips along fold limbs, forming the lower parts of the mountain chains and the slopes bordering the valleys (Fig. 5).

The Garschella (Aptian-Cenomanian) and Seewerkalk (Albian-Santonian) formations consist of thin, discontinuous sandstone and limestone (Föllmi 1986).
The Amdener formation (Santonian-Campanian) is formed of clayey marl with strong cleavage; it is hundreds of metres thick, but only ca. $70 \mathrm{~m}$ can be observed in the study area. A small tectonic klippe of the Ultrahelvetic Liebensteiner nappe occurs in the eastern part of the area but plays no role for this study.

Quaternary deposits cover the entire wide and flat valley floor of Bezau, while the elevated areas are only locally covered with thin moraine, rock debris and rock fall material.

\section{FOLDS AND FAULTS}

Structurally, the area is characterised by E-W trending, north-verging flexural-shear folds with wavelengths and amplitudes ranging between a few hundred meters and $1 \mathrm{~km}$ (Figs. 4 and 5). The mountain chain represents both a culmination of fold axes and an anticlinorium, about $2 \mathrm{~km}$ wide. Anticlines often form ridges; synclines form valleys.

Most folds are not continuous; they end at faults, unify with neighbouring folds or are replaced by other structures. We numbered the anticlines from $\mathrm{S}$ to $\mathrm{N}$ using roman numerals; synclines are numbered by combining the numerals of the bordering anticlines. The fold pattern gets simpler in a western direction: in the eastern part, there are six anticlines, while there are only two anticlines and one syncline at the western border. Three fold structures predominate; all are visible on the photo in Fig. 2: anticline II forms the Luguntenkopf-Hälekopf 


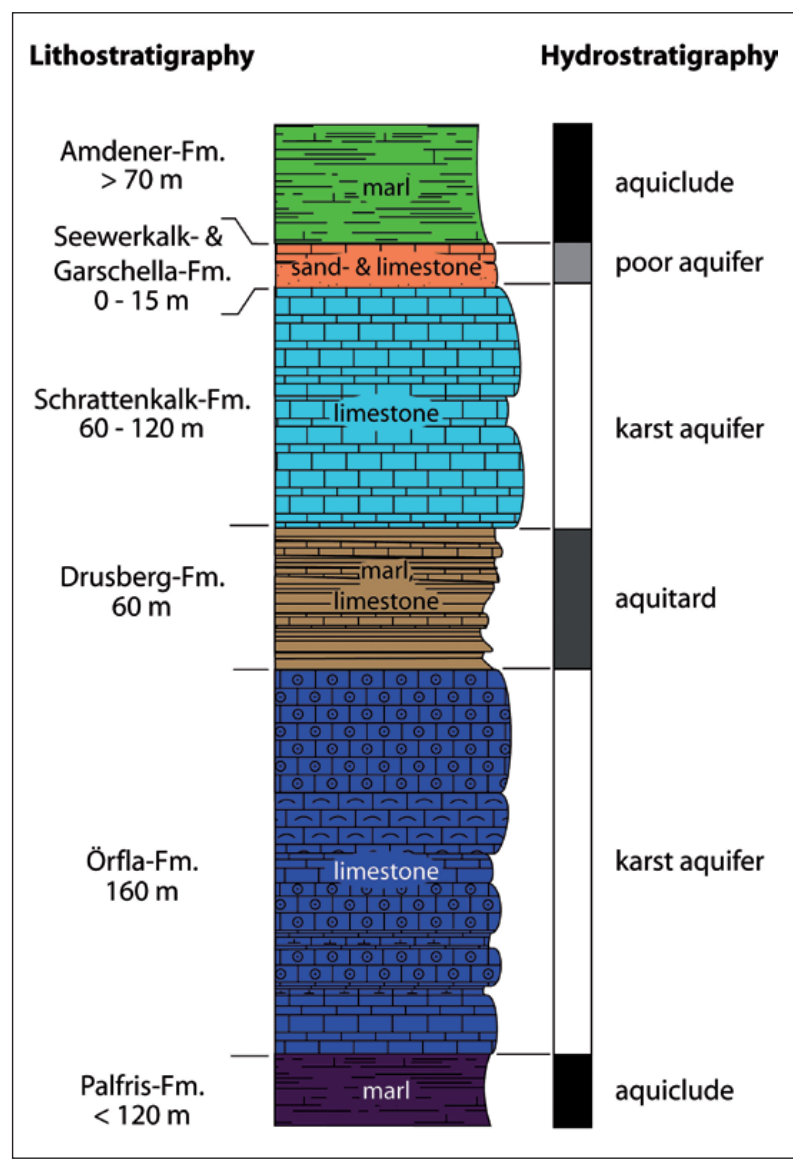

Fig. 3: Lithostratigraphic profile of the Winterstaude area, and translation into hydrostratigraphy.

ridge south of the Winterstaude chain. Syncline II/III forms the Grebentobel valley and plunges from the culmination at the eastern border of the area with $8-10^{\circ}$ in a western direction below the valley floor, toward an axial depression. Anticline V is the "backbone" of the Winterstaude chain, although its summit is formed by the bordering anticline VI.

The fault pattern is characterised by high-angle reverse faults (thrusts) parallel to the fold axes, and two systems of strike-slip faults that run across the folds (Fig. 4). A large high-angle reverse fault thrusts the southern limb of anticline $\mathrm{V}$ on top of its northern limb. The fault surface dips $60-70^{\circ}$ to the south and the displacement reaches $500 \mathrm{~m}$. A system of left-lateral extensional strike slip faults strikes approximately NE; their displacement often ranges between 40 and $70 \mathrm{~m}$. These faults are clearly visible at the eastern part of anticline II (Figs. 2 and 4 ); in other parts of the area, soil and vegetation make it difficult to recognise these faults in the field. NW faults with right-lateral displacement are less prominent. The joint and fracture pattern shows three dominant directions: S-N (most frequent), SE-NW and NE-SW.

\section{HYDROSTRATIGRAPHY AND KARSTIFICATION}

Based on field observations and hydrogeologic considerations, lithostratigraphy is translated into hydrostratigraphy (Fig. 3). There are two karstifiable formations: Örfla and Schrattenkalk Limestone, constituting a lower and upper karst aquifer. The Örfla Limestone is underlain by Palfris Marl (the regional aquiclude), the two limestones are separated by Drusberg Marl, and the Schrattenkalk Limestone is locally covered by Amdener Marl and other formations.

The Örfla formation is formed by impure limestone that is highly fractured but shows few dissolution phenomena and karst landforms (Fig. 2). Only scarce dolines, shafts and karren were found in the study area. Slopes are often steep $\left(30-40^{\circ}\right)$, but there is little surface runoff.

The Drusberg Marl is generally of low permeability but includes several karstifiable limestone banks. It forms an aquitard between the lower and upper karst aquifers and is ca. $60 \mathrm{~m}$ thick, i.e., in the same order of magnitude as the displacement of the NE faults.

The Schrattenkalk Limestone is the most important karst formation in the Helvetic zone and includes two of the world's largest caves: the Hölloch and the Siebenhengste-Hohgant cave system in the Swiss Alps (Häuselmann et al. 2003; Jeannin 2001). Numerous tracer tests in Schrattenkalk karst systems confirmed very high linear flow velocities. Springs show fast and marked responses to hydrologic events (Goldscheider 2005; Göppert \& Goldscheider 2008). In the study area, the limestone is often covered with soil and overgrown with forest. Karren are developed below the soil; aligned dolines follow faults or fracture zones. There is no surface runoff, and many allogenic streams from adjacent marl zones sink underground.

The thin and discontinuous Garschella and Seewerkalk formations play no role in the local hydrogeology. The Amdener Marl has very low permeability and acts as aquiclude on top of the Schrattenkalk karst aquifer. Outcrops of this marl always drain by surface runoff. Quaternary deposits below the wide valley floor constitute an alluvial aquifer. Depths to water table range between a few metres and $22 \mathrm{~m}$. Equipotential lines show flow to the SW, indicating recharge from the Winterstaude massif (Fig. 6).

\section{CLIMATE, SPRINGS AND FLOWING SURFACE WATERS}

The climate is characterised by abundant rain and snow, with an annual precipitation of ca. $1900 \mathrm{~mm}$ and mean air temperatures of $\mathrm{ca} .7^{\circ} \mathrm{C}$ (data from two nearby weath- 


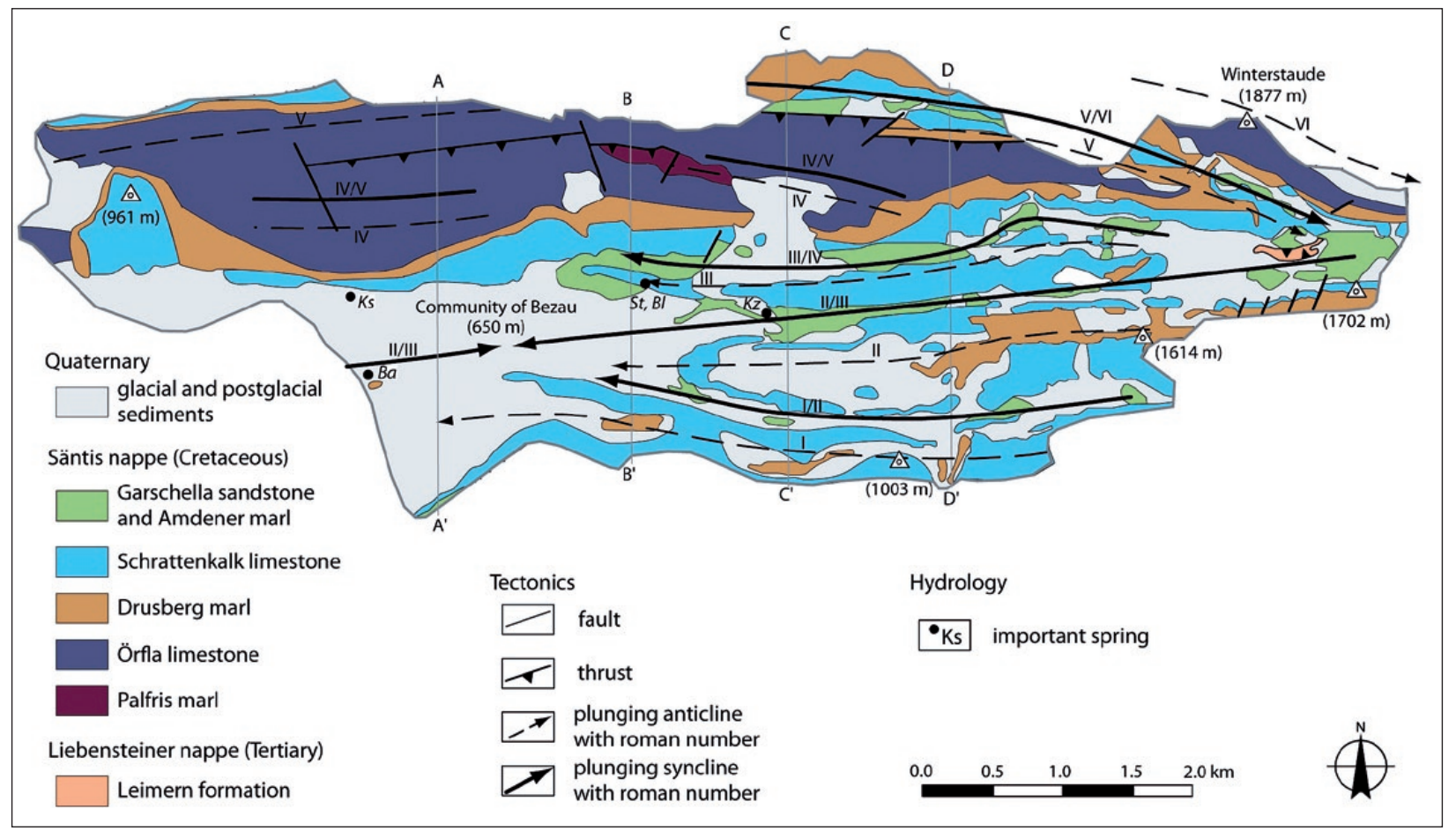

Fig. 4: Geologic map of the study area, showing also the fold axes (with roman numerals), faults and thrusts, relevant springs and the traces of the geologic sections in Fig. 5. The perimeter of this and all following maps corresponds to the area mapped in detail for this project, for the community of Bezau.

er stations at 681 and $613 \mathrm{~m}$ asl). Higher precipitations and lower temperatures $\left(-0.6^{\circ} \mathrm{C} / 100 \mathrm{~m}\right)$ occur at higher altitudes. During winter, most of the area is covered by snow.

The Bregenzerach River flows SE-NW along the western margin of the area and represents the regional base level (Fig. 6). As the Winterstaude massif consists of a folded sequence of low and high permeability formations, there are both surface and underground drainage, which intensively interact. Streams either flow E-W along the troughs of plunging synclines, or N-S direction, following the dip of the strata. Detailed discharge data are not available for most streams and springs, with the exception of drinking water springs where the State Water Survey (Landeswasserbauamt) measures flow and provided data for this study. Other flow data presented here are based on a limited number of measurements using simple methods (salt dilution, volumetric), along with estimations and observations by locals.

The Grebentobel stream drains the eastern part of the area and follows syncline II/III. Small springs around the Stonger Moor (Fig. 2) at the eastern border of the area feed a stream sinking into Schrattenkalk via one permanent and several intermittent swallow holes $(S h)$. During average summer conditions, ca. $10 \mathrm{~L} / \mathrm{s}$ sink underground. Shortly below (200 $\mathrm{m}$ linear distance), the source of the Grebentobel stream (Gt) discharges from open fractures. The stream alternately flows on limestone, marl and gravel. Although the location of the spring would suggest connection to $S h$, natural tracers (electric conductivity, temperature, hydrochemical and microbial data) show two different water types (Werz 2001). During dry periods, the Grebentobel stream dries up in parts. During high-water conditions, there is inflow from a stream following syncline III/IV.

The Kreuzboden spring $(\mathrm{Kz})$, located at the right side of the Grebentobel stream at $770 \mathrm{~m}$, is used as a drinking water source for Bezau. The water is abstracted from gravel by horizontal drainage tubes $2 \mathrm{~m}$ below ground. Discharge usually ranges between ca. 2 and $20 \mathrm{~L} / \mathrm{s}$. On the alluvial valley floor, the Grebentobel stream loses water by seepage, unites with another stream from syncline I/II and eventually flows into the Bregenzerach River.

The Dorfbach stream is fed by several tributaries from the south slope of the Winterstaude chain, but the main inflow comes from two neighbouring karst springs at $690 \mathrm{~m}$ discharging from Schrattenkalk Limestone: Stuole spring $(S t)$ is used for drinking water supply and discharges ca. 10-100 L/s; Discharge at Bleile spring $(B l)$ is similar but difficult to measure. Below these springs, the karst aquifer plunges under the valley.

The Kressbach spring $(K s)$ is situated at $620 \mathrm{~m}$ asl on the valley floor, near below a Schrattenkalk Limestone outcrop at the base of the mountain chain. The 


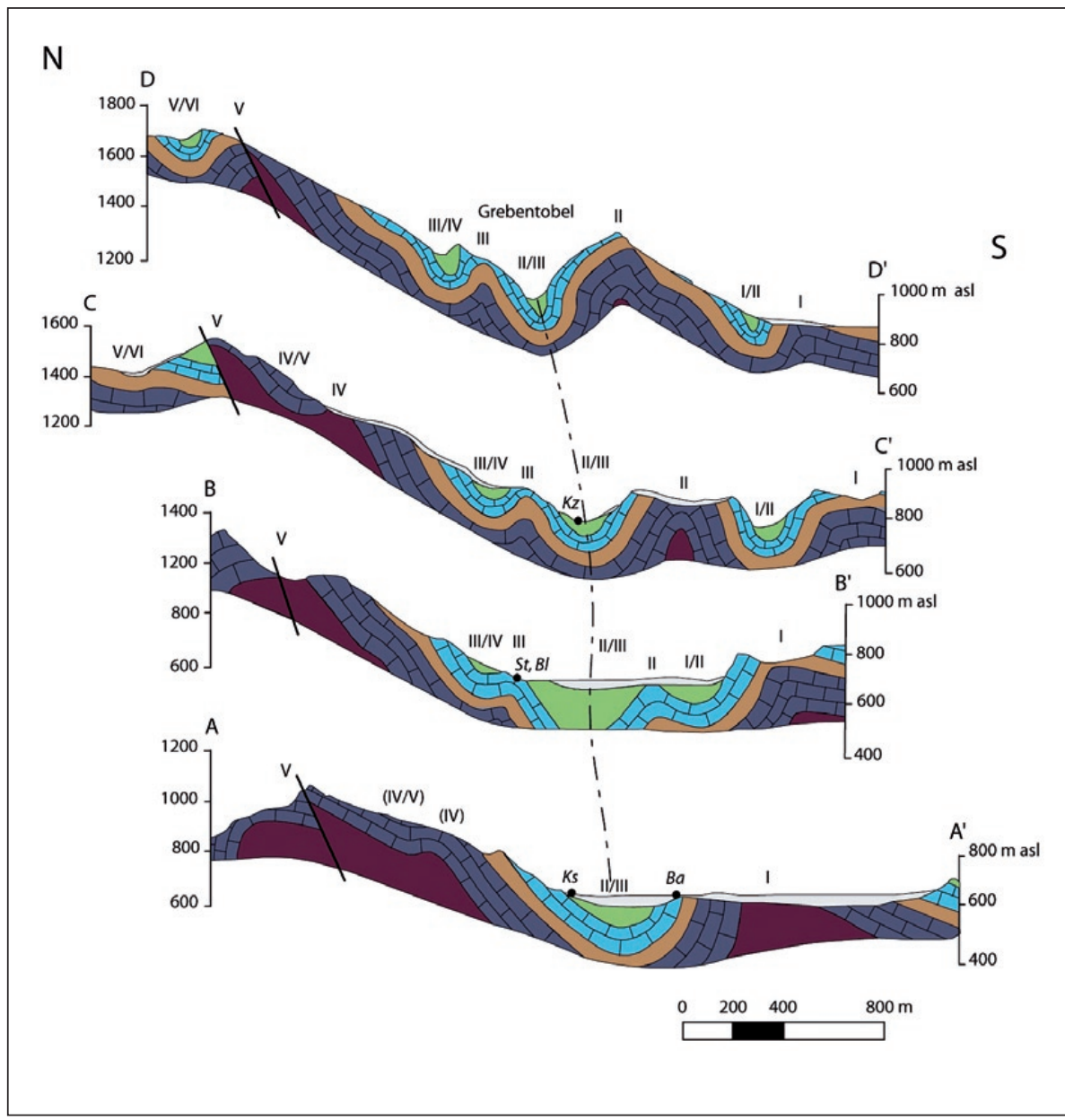

spring consists of several orifices and discharges ca. 30$300 \mathrm{~L} / \mathrm{s}$. Due to its sufficient discharge and good quality, it is a promising future drinking water source. Water level, conductivity, temperature and turbidity show significant reactions on hydrologic events.

At the western margin of the valley floor, close to the right, eastern bank of the Bregenzerach River at $617 \mathrm{~m}$ asl, a large spring $(B a)$ discharges from gravel, with a flow rate of ca. $40-500 \mathrm{~L} / \mathrm{s}$. Geologic considerations indicate that Schrattenkalk Limestone is present close below ground, belonging to the southern limb of syncline II/III.

Fig. 5: Geologic profiles of the Winterstaude area (location of the profiles and legend: Fig. 4). Syncline II/III forms the Grebentobel valley in the eastern part of the area and plunges under the wide and flat alluvial valley floor of Bezau toward the west. Locations of springs are also shown.

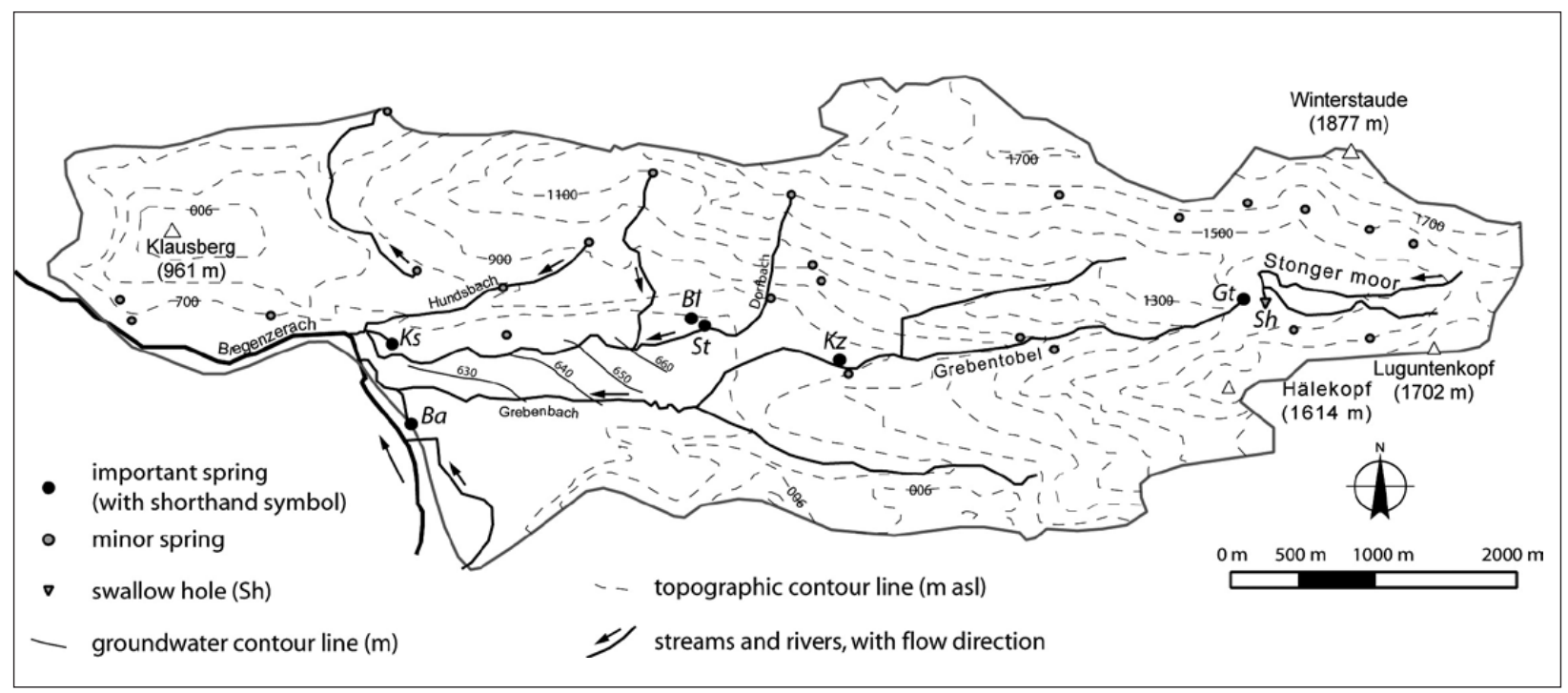

Fig. 6: Topography, springs and flowing surface waters in the Winterstaude area. 


\section{MULTI-TRACER TEST}

\section{GOALS AND EXPERIMENTAL SET UP}

A multi-tracer test with seven injections was carried out during medium to low-flow conditions in September 2000 , in order to characterise the hydraulic properties of the two karst aquifers and their interaction, to investigate the influence of geologic structures on the drainage pattern, to delineate the catchments of all relevant springs, particularly those used for drinking water supply, and to obtain information on contaminant transport. Five different fluorescent dyes were selected as tracer: Naphthionate, Pyranine, Uranine, Eosin and Sulforhodamin B (short: SulfoB). Two of them were used twice, but interference could be excluded as the respective injection sites are hydrogeologically clearly separated. Pyranine is biodegradable and was thus used for short distances and less relevant injections, while the other dyes are known for their favourable properties (Goldscheider et al. 2008). Injection points are shown in Fig. 7; tracer types and quantities are summarised in Tab. 1.
IP3 is the Grebentobel stream $500 \mathrm{~m}$ upstream from Kreuzboden spring at $810 \mathrm{~m}$. The goal was to check if this drinking water source gets inflow from surface water. During the experiment, the stream was seeping into gravel downstream the injection point. Naphthionate was selected as tracer to avoid visible colouring, but a relatively large quantity $(5 \mathrm{~kg})$ was injected to obtain clear results.

In order to assess the vulnerability of the Kreuzboden spring $(\mathrm{Kz})$ to local contamination, $100 \mathrm{~g}$ of Pyranine was released at the land surface, directly above the drainage tubes, over an area of $20 \mathrm{~m}^{2}$ (IP4), followed by an artificial rainfall of $33 \mathrm{~mm}\left(2,000 \mathrm{~L}\right.$ over $\left.60 \mathrm{~m}^{2}\right)$, which corresponds to a typical storm rainfall. As IP3 and IP4 are local, small-scale experiments, it was possible to use the same dyes again at two other, remote injection points.

The wastewater of a cable car station, a restaurant and several farmhouses seeps into rock fall material covering Schrattenkalk Limestone on a steep slope directly

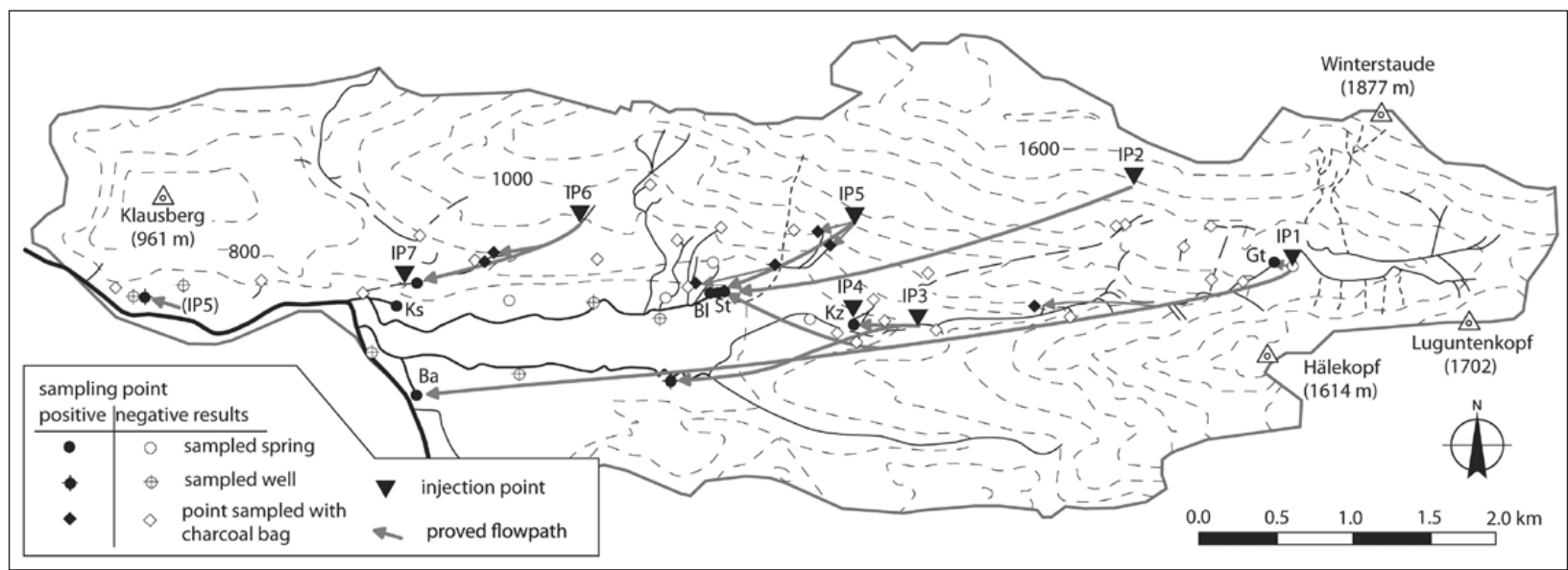

Fig. 7: Injection points (IP1-IP7), monitoring sites and established connections of the multi-tracer test in the Winterstaude karst system.

The first injection point (IP1) is the swallow hole (Sh) at the Stonger Moor at $1360 \mathrm{~m}$, where a stream frequently contaminated with bacteria sinks into Schrattenkalk in the upper section of syncline II/III. $2 \mathrm{~kg}$ of Eosin were injected to characterise the hydrogeologic role of this syncline and evaluate the impact of the contaminated stream on the springs.

A small, dry karst shaft in Örfla Limestone at $1,490 \mathrm{~m}$ served as injection point for $3 \mathrm{~kg}$ of SulfoB (IP2). 2,000 L of flushing water were provided by the fire brigade. The goal was to obtain information on the hydraulic properties of this karst aquifer and its possible connection with the Schrattenkalk aquifer. above the two drinking water springs of Bezau. In order to evaluate the impact of this microbial hazard on the springs, $2 \times 0.5 \mathrm{~kg}$ of Uranine was injected into the two main wastewater channels (IP5).

On the slope above Kressbach spring (Ks), an intermittent stream follows a zone of Drusberg Marl. In its upper section, the stream sinks into the northward bordering Örfla Limestone under low-water conditions; $2 \mathrm{~kg}$ of Pyranine was injected there (IP6). In its lower section, the stream often sinks into Schrattenkalk Limestone; 1 $\mathrm{kg}$ of Naphthionate was injected there (IP7). Both injections intended to check for inflow from the two karst aquifers to the spring. 
After the injections, all springs, streams and observation wells in the area were sampled for up to 68 days (Fig. 7). At the most relevant springs, water samples were taken manually in $50 \mathrm{~mL}$ brown-glass bottles and by three auto-samplers, while charcoal bags were installed at less important sites and at springs where the arrival of tracers was considered unlikely. At selected sites, both water samples and charcoal bags were used. Water samples and the eluates from charcoal samples were analysed using a Perkin Elmer spectrofluorometer.

\section{RESULTS}

Positive results were obtained for six of the seven injections; only Naphthionate from IP7 was not recovered. Fig. 7 shows established connections; Tab. 1 summarised the results; Figs. 8 and 9 show relevant tracer breakthrough curves (BTCs). The complete results can be found in Neukum (2001).

Eosin from IP1 was first detected at the Stuole spring $(S t)$ and the neighbouring Bleile spring $(B l) 45 \mathrm{~h}$ after injection. The respective maximum concentrations of $70.1 \mu \mathrm{g} / \mathrm{L}(S t)$ and $80.2 \mu \mathrm{g} / \mathrm{L}(B l)$ also occurred simultaneously after $60 \mathrm{~h}$. Tracer recoveries reach $131.6 \mathrm{~g}$ or $6.58 \%(S t)$ and ca. $120 \mathrm{~g}$ or $6 \%(B l)$ (discharge values at $\mathrm{Bl}$ are less precise than at $\mathrm{St}$, resulting in less precise determination of tracer recovery). The similar results obtained at both springs indicate that they are orifices of the same system (Fig. 8). The results also demonstrate drainage in the Schrattenkalk aquifer along the westward plunging syncline II/III, as well as the risk of spring water contamination resulting from the sinking stream at Stonger Moor.

Despite its short distance from IP1 (200 m), Eosin was not detected in water samples taken at the Grebentobel spring $(G t)$ during the first eight hours after injection, confirming natural tracer data, which showed that the spring water is different than water from the swallow hole (see above). However, charcoal bags installed at $G t$ showed positive trace detections later on. Minor traces were detected in two water samples from Kreuzboden spring $(K z)$, tapped from gravel by drainage tubes; the

Tab. 1: Summary of the experimental set-up of the tracer tests and the results for all relevant springs, with mean discharge (Q) during the experiment (where available). Results include the time of maximum concentration or peak time ( $t$ in $h)$, maximum concentration normalised by input mass ( $c / M$ in $\left.10^{-6} \mathrm{~m}^{-3}\right)$, tracer recovery $(R$ in \%). White box: spring was analysed for the respective tracer; grey box: not analysed, but connection impossible; + connection proven with charcoal bags; - analysed, but tracer not detected.

\begin{tabular}{|c|c|c|c|c|c|c|c|c|}
\hline \multirow{2}{*}{$\begin{array}{c}\text { Spring } \\
\text { no. }\end{array}$} & \multicolumn{7}{|c|}{ Injection point / altitude / tracer type / injection quantity } & \multirow{5}{*}{$\begin{array}{c}\text { Results } \\
\mathrm{t}_{\mathrm{p}} \\
\mathrm{c} / \mathrm{M} \\
\mathrm{R}\end{array}$} \\
\hline & $I P 1$ & $I P 2$ & IP3 & IP4 & IP5 & IP6 & $I P 7$ & \\
\hline & $1360 \mathrm{~m}$ & $1490 \mathrm{~m}$ & $810 \mathrm{~m}$ & $770 \mathrm{~m}$ & $1200 \mathrm{~m}$ & $920 \mathrm{~m}$ & $690 \mathrm{~m}$ & \\
\hline $\mathrm{Q}$ & Eosin & SulfoB & Naphth. & Pyranine & Uranine & Pyranine & Naphth. & \\
\hline$(\mathrm{L} / \mathrm{s})$ & $2 \mathrm{~kg}$ & $3 \mathrm{~kg}$ & $5 \mathrm{~kg}$ & $100 \mathrm{~g}$ & $1 \mathrm{~kg}$ & $2 \mathrm{~kg}$ & $1 \mathrm{~kg}$ & \\
\hline Gt & + & - & & & & & & \\
\hline $\mathrm{Kz}$ & 77.2 & - & 9 & 0.33 & - & & & $\mathrm{h}$ \\
\hline \multirow{2}{*}{6.0} & 0.21 & & 433 & 1161 & & & & $10^{-6} \mathrm{~m}^{-3}$ \\
\hline & 0.0001 & & 12.9 & 4.48 & & & & $\%$ \\
\hline St & 60.1 & 271.7 & & & 76.9 & - & & $\mathrm{h}$ \\
\hline \multirow[t]{2}{*}{33} & 35.1 & 6.62 & & & 1.34 & & & $10^{-6} \mathrm{~m}^{-3}$ \\
\hline & 6.58 & 6.25 & & & 1.66 & & & $\%$ \\
\hline $\mathrm{BI}$ & 60.2 & 271.0 & & & 77.0 & - & & $\mathrm{h}$ \\
\hline \multirow[t]{2}{*}{ ca. 30} & 40.1 & 6.64 & & & 0.89 & & & $10^{-6} \mathrm{~m}^{-3}$ \\
\hline & ca. 6 & ca. 4 & & & ca. 2 & & & $\%$ \\
\hline Ks & - & - & & & - & - & - & \\
\hline $\mathrm{Ba}$ & 211.3 & - & & & - & - & & $\mathrm{h}$ \\
\hline \multirow[t]{2}{*}{65} & 5.65 & & & & & & & $10^{-6} \mathrm{~m}^{-3}$ \\
\hline & 16.3 & & & & & & & $\%$ \\
\hline
\end{tabular}




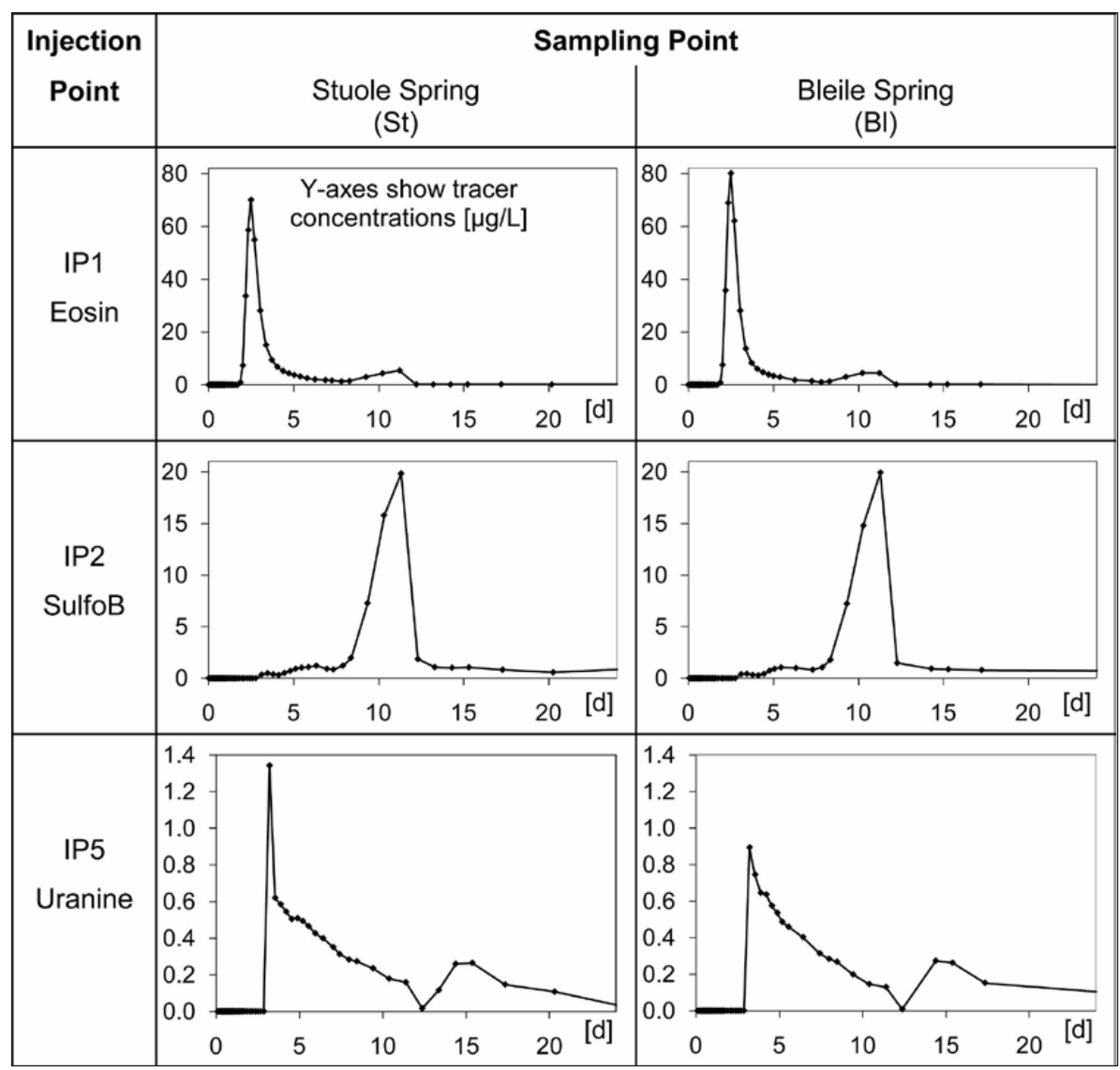

Fig. 8: Breakthrough curves (BTCs) recorded at the Stuole spring and the nearby Bleile spring. The results for the two springs are similar, confirming that they are outlets of the same aquifer system and receive inflows from both the Schrattenkalk karst aquifer (IP1 and IP5) and the Örfla karst aquifer (IP2).

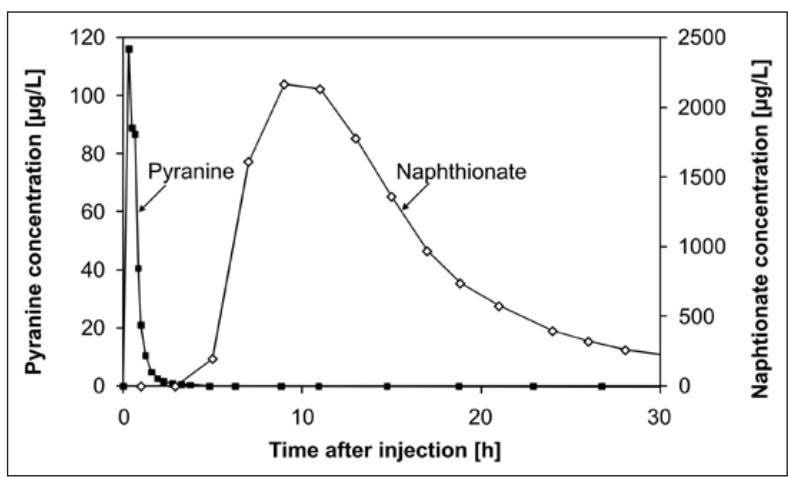

Fig. 9: BTCs of Pyranine (IP4) and Naphthionate (IP3) recorded at Kreuzboden spring $(\mathrm{Kz})$, illustrating its high vulnerability to contamination from the land surface and the nearby stream, respectively.

tracer probably reached the spring by infiltration from the stream.

Six days after injection, Eosin also reached the spring at the Bregenzerach River $(B a)$, situated at the western margin of the wide alluvial valley floor (Fig. 7). This finding confirms that the spring is connected to the Schrattenkalk karst aquifer, which is present close to the surface, although it does not outcrop but is covered by gravel (Fig. 5).

SulfoB (IP2) was injected into the Örfla karst aquifer and reached the Stuole $(S t)$ and Bleile $(B l)$ springs, which discharge from Schrattenkalk Limestone. The tracer was first detected after 3 days at low levels, while the peaks of the two BTCs occurred after 11 days, with identical maximum concentrations of $19.9 \mu \mathrm{g} / \mathrm{L}$ (Fig. 8 ) and recoveries of $6.25 \mathrm{~g}$ and ca. $4 \%$, respectively. These findings demonstrate hydraulic connection between the lower and upper karst aquifer and confirm again that the two springs drain the same system.

Naphthionate (IP3), injected into the Grebentobel stream, and Pyranine (IP4), released at the meadow above the drainage tubes of the Kreuzboden spring $(\mathrm{Kz})$, both arrived at the spring after $9 \mathrm{~h}$ (Naphthionate) and $20 \mathrm{~min}$ (Pyranine) at high concentration levels, demonstrating the vulnerability of this drinking water source to contamination from the stream and meadow (Fig. 9). These results are of high practical relevance for the community of Bezau.

Uranine (IP5) was injected in two wastewater streams seeping into rockfall material covering Schrattenkalk Limestone. The tracer reached the Stuole $(S t)$ and Bleile $(B l)$ springs three days after injection and reached maximum concentrations in the first positive samples. The peaks of the BTCs are narrow, followed by a slow concentration decline (Fig. 8). Recovery reached $1.66 \mathrm{~g}$ and ca. $2 \%$, respectively. These findings demonstrate that the two springs, although located at the northern limb of syncline II/III, receive inflow from the northward bordering syncline III/IV. The results also show that the wastewater reaches the springs. Uranine was also detected in charcoal bags from three other small springs and two observation wells. 
The two tracers injected in the upper and lower section of the stream above the Kressbach spring $(K s)$ did not reach this spring. Pyranine (IP6) was only detected in three small springs further downstream; Naphthionate (IP7) was not recovered at any monitoring site. Negative Pyranine results should be considered with caution, as this tracer is microbiologically unstable; in some cases, large quantities have disappeared without a trace (Goldscheider et al. 2003). None of the tracers injected in the entire area were detected at Kressbach spring, although its position close to outcrops of Schrattenkalk Limestone at the northern limb of syncline II/III (Fig. 5) would suggest possible connection to several of the injection points, particularly IP1 in the upper section of this syncline. At the current level of understanding, it is therefore not possible to determine the origin of the springwater. Further tracer tests and natural tracer studies would be required to delineate the catchment of this spring.

\section{CONCEPTUAL MODEL OF KARST DRAINAGE}

The Winterstaude mountain chain consists of a sequence of marl and limestone formations, including two relevant karst aquifers: The Örfla Limestone is $160 \mathrm{~m}$ thick and forms the lower karst aquifer, underlain by a thick regional marl aquiclude; the Schrattenkalk Limestone is $100 \mathrm{~m}$ thick and constitutes the upper karst aquifer; the intermediate marl is $60 \mathrm{~m}$ thick.

The Örfla Limestone forms the "backbone" of the mountain chain, while the Schrattenkalk outcrops near the basis of the mountain chain and on the slopes surrounding the Grebentobel valley (syncline II/III). The Örfla Limestone forms a large recharge area, but all relevant springs discharge from Schrattenkalk. This observation already suggests that water from the Örfla aquifer enters the Schrattenkalk aquifer, probably via NE faults cutting through the intermediate marl (Fig. 2). This was confirmed by the injection of a tracer into the Örfla aquifer (IP2) that reached two main karst springs discharging from Schrattenkalk (Fig. 10).

Due to the alternation of marl aquicludes and karst aquifers, underground flow is generally parallel to the stratification. The high degree of "stratigraphic flow control" (Goldscheider 2005) causes a high degree of structural flow control by the folds. In the elevated areas, above the base level of the karst system, the troughs of the plunging synclines form the main flow paths. The crests of the anticlines form local drainage divides and the culmination line of the folds at the eastern margin of the area forms a regional drainage divide. However, some of the folds are discontinuous and so their hydraulic function is limited.

Near the base level, groundwater overflows the anticlines, so that water from neighbouring synclines mix. Therefore, springs are usually not located in the troughs of synclines, but at the crests of anticlines or on fold limbs: Stuole and Bleile springs ( $S t$ and $B l$ ) are situated near the crest of anticline III and receive inflow from the two bordering synclines; the spring at the Bregenzerach
River $(B a)$ is situated on the southern limb of syncline II/III.

Four different hydrologic processes drain the mountain chain: surface runoff, shallow karst water flow, infiltration into the alluvial aquifer, and deep karst water flow:

Surface runoff occurs on marl outcrops, i.e., along the cores of synclines and on the limbs between the two limestone formations, where the intermittent marl forms the land surface. Surface waters either run parallel to the synclines axes or follow the slopes formed by the fold limbs. Streams often seep or sink underground when they reach karstified limestone.

Shallow karst water flow takes place above the level of the valley floor. The alpine karst system is mainly discharged by the Stuole $(S t)$ and Bleile springs $(B l)$ near the foot of the mountain chain. However, as the waters from neighbouring synclines often mix, the springs receive inflow from several subsystems.

A portion of the water from the alpine karst system recharges the alluvial aquifer below the valley floor. Tracer tests, equipotential lines (Fig. 6) and hydrologic observations show that there is both seepage of surface streams and direct inflow from karst groundwater into this alluvial aquifer.

Deep karst water flow was identified by tracer test IP1, which demonstrated that the main syncline II/III continues below the valley floor and connects the alpine karst with the spring at the Bregenzerach river $(B a)$ (Fig. 10). Below the valley floor, the Schrattenkalk aquifer is confined by Amdener Marl and Quaternary deposits.

Linear groundwater flow velocities were calculated on the basis of the BTCs. The maximum linear flow velocity is the ratio of distance and first tracer detection; the peak (or dominant) flow velocity is obtained from the time of maximum concentration.

The connection between injection point IP1 and the Stuole spring $(S t)$ follows the trough of the main syn- 


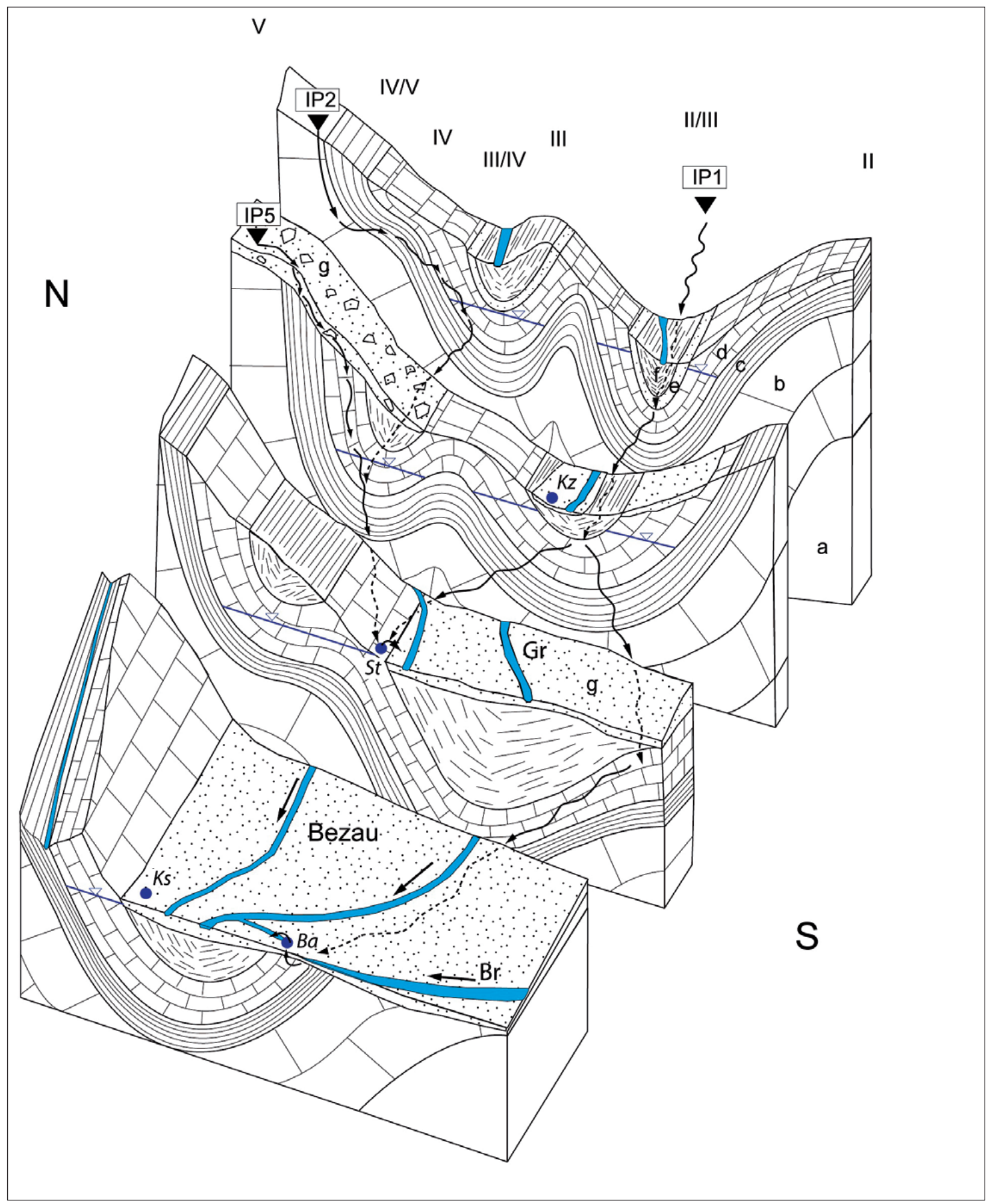

Fig. 10: Conceptual model of karst drainage in the Winterstaude area. Hydrostratigraphy: a: Palfris Marl (aquiclude), b: Örfla Limestone (lower karst aquifer), c: Drusberg Marl (aquitard), d: Schrattenkalk Limestone (upper karst aquifer), e: Garschella and Seewerkalk formations (poor aquifer), $f:$ Amdener Marl (aquiclude). Underground drainage pattern proven by tracer tests: injection point IP1 demonstrated underground drainage in the upper karst aquifer along syncline II/III below the alluvial valley floor toward spring Ba near the Bregenzerach River $(\mathrm{Br})$. IP2 demonstrated cross-formational flow from the lower to the upper karst aquifer. IP5 demonstrated that groundwater overflows anticlines near the base level. 
cline II/III and is characteristic for the shallow Schrattenkalk karst aquifer. The maximum flow velocity along this pathway is $91 \mathrm{~m} / \mathrm{h}$, the dominant flow velocity is $73 \mathrm{~m} / \mathrm{h}$.

The deep karst aquifer below the valley floor can be characterised indirectly by comparing the BTCs of the Stuole spring (shallow karst) and the spring at the Bregenzerach river (deep karst). The maximum flow velocity in the deep aquifer is $22 \mathrm{~m} / \mathrm{h}$, while the observed BTC does not allow reliable determination of the dominant flow velocity.

The maximum and dominant (modal) flow velocities between IP2 in the Örfla Limestone and the Stuole spring are $41 \mathrm{~m} / \mathrm{h}$ and $12 \mathrm{~m} / \mathrm{h}$, respectively. As the flowpath includes unsaturated and saturated flow in the Örfla aquifer, a passage through Drusberg Marl and subsequent flow in the Schrattenkalk aquifer, the calculated velocities represent the entire system and not the flow velocity in the Örfla aquifer. The relatively high velocities and tracer concentrations suggest rapid and direct connection between the two karst aquifers along a fault with a displacement that is large enough to create contact between the two limestone formations.

The total tracer recoveries obtained for the three most relevant injections shown in Fig. 10 are quite low: $29 \%$ for IP1, 12\% for IP2, and 4\% for IP5. The absence of a naturally sinking stream at IP2 and the resulting adsorption of tracer in the unsaturated zone may partly explain the low recovery obtained for this injection. Storage in micro-fissures and in the porous rock matrix can also cause low recoveries, as demonstrated by Neukum et al. (2008). However, low recoveries can also indicate deep infiltration into intermediate to regional flow systems with distant, unmonitored drainage locations. Spring $B a$ represents the drainage point of an intermediate flow system: $16.3 \%$ of the tracer injected at IP2 has been recovered at this spring, illustrating the importance of this flow system for the drainage of the alpine karst area. However, even larger and deeper flow systems with remoter discharge location have to be expected in this region, because the two karst aquifers continue below the level of the valley.

\section{CONCLUSIONS}

The relations between geologic structures and underground karst drainage in folded multi-aquifer systems are more complicated than in single-aquifer systems. In both types of karst aquifer systems, the troughs of synclines often form the main drainage pathways, while anticlines act as local water divides, particularly in the zone of shallow karst, where the aquifer basis is above the hydrologic base level so that flow occurs near the aquifer basis. In the zone of deep karst, fold structures are often completely saturated with groundwater so that flow across anticlines is possible. In multi-aquifer systems, cross-formational flow across intermediate marl aquitards can occur (Toth 1978), as also discussed by Häuselmann (2005) who directly observed such phenomena in two large cave systems in the Swiss Alps. In the present case, groundwater from the lower karst aquifer (Örfla Limestone) travels across an intermediate marl formation towards the upper karst aquifer (Schrattenkalk Limestone), presumably along faults. This finding is important for the delinea- tion of source protection zones in multi-aquifer systems, which should include not only the recharge areas of the karst aquifer under consideration (Ravbar \& Goldscheider 2007), but also the under- or overlying aquifers whenever cross-formational flow has to be expected.

Different types of hierarchical flow systems, as defined by Toth $(1962,1999)$, have been identified in the study area: Local flow systems connect the elevated recharge areas with the karst springs at the foot of the mountain chain. An intermediate flow system extends below the alluvial valley floor and connects the alpine karst with a spring near the Bregenzerach River representing the regional base level. Last but not least, the generally low tracer recoveries point to deep infiltration into regional flow systems, such as the circulation systems below the northern foreland basin on the Alps (Keller 1992), although storage of tracer in micro-fissures and matrix of the limestones can also cause low recoveries. 


\section{ACKNOWLEDGEMENTS}

The Vorarlberger Naturschau (inatura) and the community of Bezau funded this study; Umweltinstitut Vorarlberg and Landeswasserbauamt Bregenz provided data and information. We thank all friends and colleagues who contributed to this study, and David Drew for proofreading.

\section{REFERENCES}

Burkhard, M., Atteia, O., Sommaruga, A., Gogniat, S. \& D. Evard, 1998: Tectonics and hydrogeology of the Neuchatel Jura.- Eclogae Geologicae Helvetiae, 91, 1, 177-183.

Föllmi, K.B., 1986: Die Garschella- und Seewer Kalk-Formation (Aptian-Santonian) im Vorarlberger Helvetikum und Ultrahelvetikum.- Mitteilungen aus dem geologischen Institut der Eidg. Technischen Hochschule und der Universität Zürich, Neue Folge, 262, $1-391$.

Goldscheider, N., 2005: Fold structure and underground drainage pattern in the alpine karst system Hochifen-Gottesacker.- Eclogae Geologicae Helvetiae, $98,1,1-17$.

Goldscheider, N., Hötzl, H., Käss, W. \& W. Ufrecht, 2003: Combined tracer tests in the karst aquifer of the artesian mineral springs of Stuttgart, Germany.- Environmental Geology, 43, 8, 922-929.

Goldscheider, N., Meiman, J., Pronk, M. \& C. Smart, 2008: Tracer tests in karst hydrogeology and speleology. International Journal of Speleology, 37, 1, 27-40.

Göppert, N. \& N. Goldscheider, 2008: Solute and colloid transport in karst conduits under low- and highflow conditions.- Ground Water, 46, 1, 61-68.

Gremaud, V., Goldscheider, N., Savoy, L., Favre, G. \& H. Masson, 2009: Geological structure, recharge processes and underground drainage of a glacierised karst aquifer system, Tsanfleuron-Sanetsch, Swiss Alps.- Hydrogeology Journal, 17, 8, 1833-1848.

Häuselmann, P., 2005: Cross-formational flow, diffluence and translucence observed in St. Beatus Cave and Sieben Hengste (Switzerland).- International Journal of Speleology, 34, 1-2, 65-70.

Häuselmann, P., Jeannin, P.Y. \& T. Bitterli, 1999: Relationships between karst and tectonics: case-study of the cave system north of Lake Thun (Bern, Switzerland).- Geodinamica Acta, 12, 6, 377-387.

Häuselmann, P., Otz, M. \& P.Y. Jeannin, 2003: A review of the dye tracing experiments done in the Siebenhengste karst region (Bern, Switzerland).- Eclogae Geologicae Helvetiae, 96, 1, 23-36.
Herold, T., Jordan, P. \& F. Zwahlen, 2000: The influence of tectonic structures on karst flow patterns in karstified limestones and aquitards in the Jura Mountains, Switzerland.- Eclogae Geologicae Helvetiae, 93, 3, 349-362.

Jeannin, P.Y., 2001: Modeling flow in phreatic and epiphreatic karst conduits in the Hölloch cave (Muotatal, Switzerland).- Water Resources Research, 37, 2, 191-200.

Keller, B., 1992: Hydrology of the Swiss Molasse Basin - a review of current knowledge and considerations for the future. Eclogae Geologicae Helvetiae, 85, 3, 611-652.

Maloszewski, P., Stichler, W., Zuber, A. \& D. Rank, 2002: Identifying the flow systems in a karstic-fissuredporous aquifer, the Schneealpe, Austria, by modelling of environmental $\mathrm{O}-18$ and $\mathrm{H}-3$ isotopes.Journal of Hydrology, 256, 1-2, 48-59.

Neukum, C., 2001: Tektonik und Karstentwässerung im Gebirgsmassiv der winterstaude (Marktgemeinde bezau, Vorarlberg, Österreich).- Unpublished diploma thesis, University Karlsruhe.

Neukum, C., Hötzl, H. \& T. Himmelsbach, 2008: Validation of vulnerability mapping methods by field investigations and numerical modelling.- Hydrogeology Journal, 16, 4, 641-658.

Plan, L., Filipponi, M., Behm, M., Seebacher, R. \& P. Jeutter, 2009: Constraints on alpine speleogenesis from cave morphology - A case study from the eastern Totes Gebirge (Northern Calcareous Alps, Austria).- Geomorphology, 106, 1-2, 118-129.

Plan, L., Kuschnig, G. \& H. Stadler, 2010: Kläffer Spring - the major water supply spring of the Vienna water supply (Austria).- In: Kresic, N. \& Z. Stevanovic (eds.), Groundwater Hydrology of Springs. Engineering, Theory, Management, and Sustainability. Butterworth-Heinemann, pp. 411-427, Burlington.

Ravbar, N. \& N. Goldscheider, 2007: Proposed methodology of vulnerability and contamination risk mapping for the protection of karst aquifers in Slovenia.- Acta Carsologica, 36, 3, 397-411. 
Schmid, S.M., Fugenschuh, B., Kissling, E. \& R. Schuster, 2004: Tectonic map and overall architecture of the Alpine orogen. -Eclogae Geologicae Helvetiae, 97, 1, 93117.

Toth, J., 1962: A theory of groundwater motion in small drainage basins in central Alberta, Canada.- Journal of Geophysical Research, 67, 11, 4375-4387.

Toth, J., 1978: Gravity-induced cross-formational flow of formation fluids, Red Earth Region, Alberta, Canada - analysis, patterns, and evolution.- Water Resources Research, 14, 5, 805-843.
Toth, J., 1999: Groundwater as a geologic agent: An overview of the causes, processes, and manifestations.Hydrogeology Journal, 7, 1, 1-14.

Werz, H., 2001: GIS gestützte Vulnerabilitätskartierung und Vorschläge zur Ausweisung von Trinkwasserschutzzonen für die Gemeinde Bezau.- Unpublished diploma thesis, University of Karlsruhe.

Wyssling, G., 1986: Der frühkretazische Schelf in Vorarlberg und im Allgäu - Stratigraphie, Sedimentologie und Paläogeographie.- Jb. Geol. B.-Anst., 129, 1, 161-265. 